\title{
Impact on groundwater of a karstic aquifer in the informal settlement "Las Fincas" on Cozumel Island, Mexico
}

\author{
C. Koch ${ }^{1}$, O. Frausto ${ }^{2}$, S. Giese ${ }^{3}$, M. Schirmer ${ }^{1} \&$ T. Steenbeck ${ }^{1}$ \\ ${ }^{1}$ University of Applied Sciences Jena, Germany \\ ${ }^{2}$ University of Quintana Roo, Mexico \\ ${ }^{3}$ Thuringian State Institute for Environment and Geology, Germany
}

\begin{abstract}
The Yucatán Peninsula is mainly composed of limestone. Cozumel Island is part of the Yucatec carbonate platform. Dissolution processes in the limestone lead to karstification. Groundwater preferentially flows into karstic cavities. Due to its geological structure the karstic aquifer shows a high vulnerability to anthropogenic impacts. This study investigates the impact on groundwater in the area of the informal settlement "Las Fincas". Due to the informal urbanization of the settlement there is neither a public water and power supply nor a sewerage nor waste disposal system. Groundwater samples were taken in a number of domestic wells that are in use for local water supply in "Las Fincas" and tested for typical indicators of anthropogenic pollution. Distinct evidence of fecal contamination was found. The evaluation of a reference analysis of wells outside "Las Fincas" also showed a significant fecal contamination. Two aspects were considered as a reason for the fecal pollution. On the one hand there is the pollution of wastewater and feces by the local residents. On the other hand, there is the practice of the grouting of treated wastewater in deeper zones of the aquifer by the local water supplier. For further investigation a long-term monitoring was established in order to take groundwater samples and record groundwater levels frequently. The study documents the hydrodynamic and hydro chemical conditions of the aquifer and gives recommendations for the use of groundwater without any health risk.

Keywords: karstic aquifer, informal settlement, anthropogenic groundwater pollution.
\end{abstract}




\section{Introduction}

Cozumel Island is part of the Yucatec carbonate platform and is mainly composed of limestone (figure 1). Dissolution processes in the limestone lead to karstification. Groundwater preferentially flows into karstic cavities and tunnel systems. Due to its permeable structure the karstic aquifer shows a high vulnerability to anthropogenic impacts.

Cozumel Island has a total area of 478 square kilometers [5], its aquifer extends into an area of 263 square kilometers [4]. The groundwater stays in direct contact with the sea water. The lower density of the freshwater causes the freshwater lens to rest on the surrounding salt water [10]. The hydrometeorology shows the following characteristics (Hölting [8]: $\dot{h}_{\mathrm{N}}=\dot{h}_{\mathrm{Ao}}+\dot{h}_{\mathrm{Au}}+\dot{h}_{\mathrm{V}}$ ):

- $\quad$ average annual precipitation 1175 millimeters [6],

- $\quad 75$ percent evapotranspiration, 19 percent superficial drainage and 6 percent underground discharge [15],

- $\quad$ an average annual groundwater recharge of 47.5 million cubic meters [4].

CAPA (Comisión de Agua Potable y Alcantarillado) is responsible for the water supply of Cozumel. 151 wells in the center of the island are used for the production of potable water which has increased in the last decades from 1.9 in 1986 to 3.5 million cubic meters in 2015 [14].

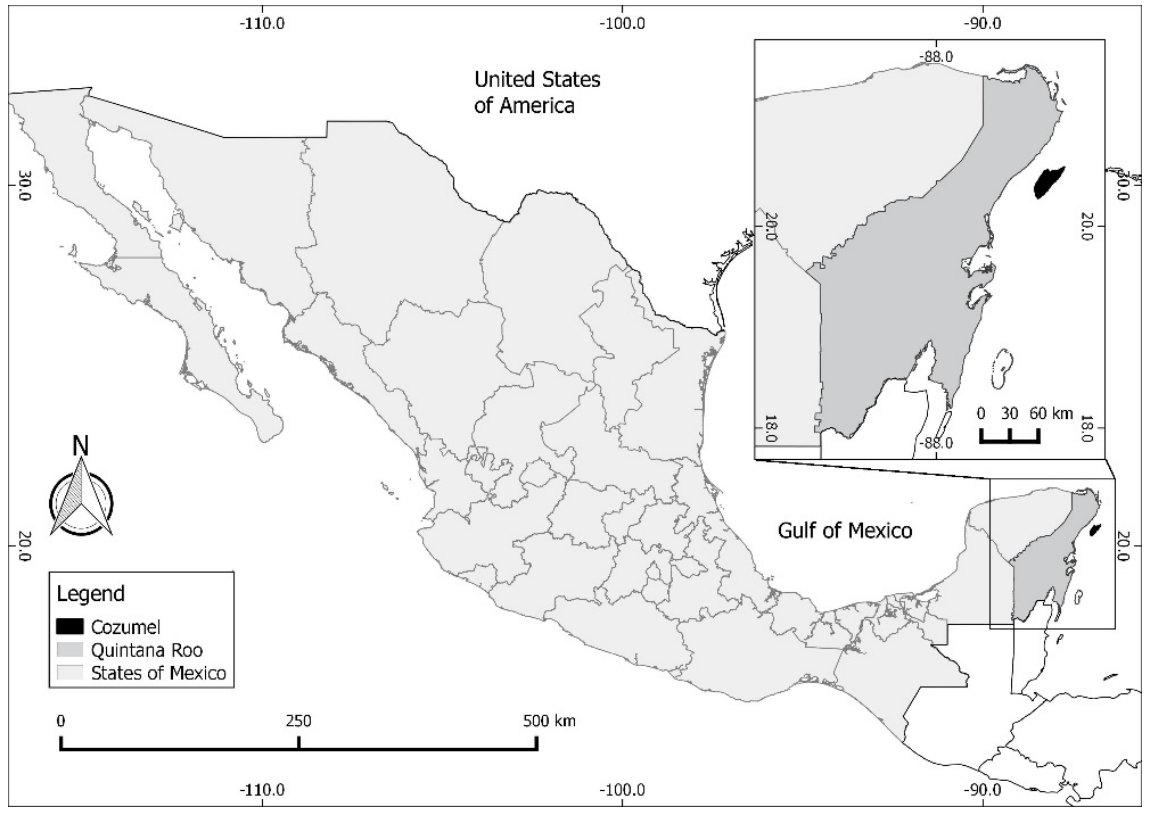

Figure 1: Cozumel in Mexico. 


\section{2 "Las Fincas"}

The informal settlement "Las Fincas" is situated on the outskirts of the municipality San Miguel de Cozumel (figure 2). Due to the informal urbanization there is neither water or power supply nor a sewerage nor waste disposal system. House construction and inhabitation of parceled lots take place without any official control. Streets are not paved. The residents of "Las Fincas" obtain water from domestic wells. Wastewater is collected in cisterns and caverns.

Due to the encountered and documented situation relating the not existing sewerage and waste disposal and the missing infrastructure for water supply the focus of the present investigation was placed on the groundwater quality of the area. With the help of a survey it was possible to get an overview of the settlement which presented the following results:

- 400 lots in total with about 1000 residents;

- 250 domestic wells;

- 180 non-drained wastewater storage basins;

- Infrequent waste disposal of private of the waste management company PASA (Promotora Ambiental de la Laguna);

- Waste is stored on the lots and sometimes burned.

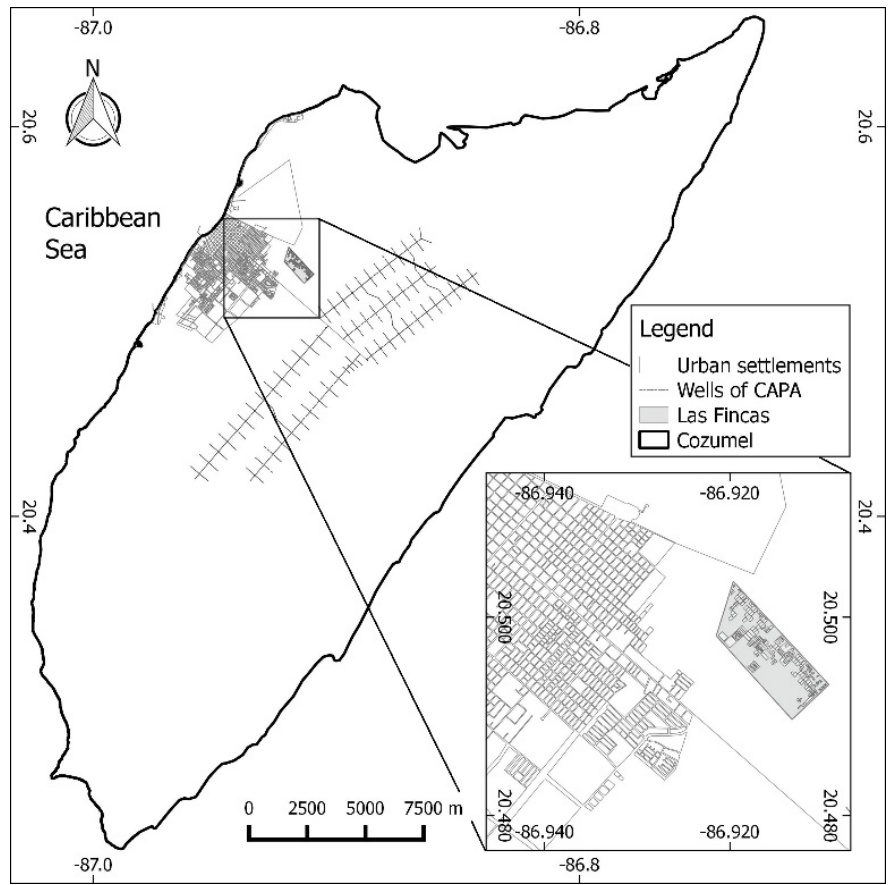

Figure 2: Las Fincas on Cozumel Island. 
It was presumed that the inconsequent waste management and inappropriate storage and disposal of waste caused a contamination of the karstic aquifer.

\section{Flow systems in karst}

Karst is Serbo-Croatian and comes from the mountains of the same name in the Slovenian Adria. Karst describes the formations that grew by corrosion of solvable rocks. This process leads to karstification which is typical for carbonate rocks (particularly limestone) and evaporates. Corrosion of carbonate takes place when water $\left(\mathrm{H}_{2} \mathrm{O}\right)$ and carbon dioxide $\left(\mathrm{CO}_{2}\right)$ of the air react to carbon acid $\left(\mathrm{H}_{2} \mathrm{CO}_{3}\right)$. After that carbon acid reacts with Carbonate to hydrocarbonate, e.g. $\mathrm{Ca}\left(\mathrm{HCO}_{3}\right)^{2}$ which dissociates in water.

$$
\mathrm{CaCO}_{3}+\mathrm{H}_{2} \mathrm{CO}_{3} \leftrightarrow \mathrm{Ca}\left(\mathrm{HCO}_{3}\right)^{2} \leftrightarrow \mathrm{Ca}^{2+}+2 \mathrm{HCO}_{3}^{-}
$$

The reason for the intensive solution processes in humid tropic climates are higher temperatures, precipitation rates, carbon dioxide contents and acids that arise from fast dissociation of organic compounds. Typical karst formations are:

a) Surface reliefs (e.g. limestone pavement, sinkholes, Polje);

b) Subterranean dissolutions forms (e.g. caverns, holes);

c) Creation of precipitation (e.g. dripstones);

d) Hydrography characterized by subterranean drainage (karst hydrography) [13].

\subsection{Hydrological conditions of Cozumel}

The island is made of reefs which date from the Oligocene and the Quaternary ages. Carbonate rocks have been exposed to karstification since their creation and formed a karstic aquifer. Only small parts of the karst system are investigated and documented by professional cave divers. These parts are used by tourism.

The karst of Cozumel is characterized by sinkholes without surface drainage. Sinkholes are called "cenotes". Subterranean discharge takes place in widely ramified cavern systems. Discharge is always directed to the sea. Due to the widely ramified caverns discharge can cover long distances by low slopes in the underground [15].

\section{Indicator bacteria}

In 2004 the Bavarian State Office for Water Management (BLfW) published a report about the quantification of diffuse contamination with fecal bacteria of bodies of water in areas in agriculture use. One of the results was that fast water movements in the soil through macrospores cause fast displacements of fecal bacteria in the soil. This presents a hazard for the groundwater. As an evidence of fecal contamination in seeping water fecal indicator bacteria were used which are also set as criteria of assessment in the European Council Directive 76/160/EEC concerning the quality of bathing water. Total coliforms and fecal coliforms are applied as indicator bacteria. Total coliforms point to fecal contamination because 
they do not only appear in the intestine of warm blooded animals. Fecal coliform bacteria (e.g. E. coli) and fecal streptococcus are accepted fecal contamination indicators of bodies of water due to the fact that they only appear in the intestine of warm blooded animals [2].

The report of the BLfW showed that under appropriate porosity of the soil a fast displacement of fecal indicator bacteria can occur. This implements a contamination of the groundwater. Organic waste and excrements of warm blooded animals were found everywhere in the informal settlement "Las Fincas".

\section{Methods}

Three samplings with different parameter spectra were realized.

\subsection{Physico-chemical parameter}

In order to determine the sample size for a screening of the domestic wells in "Las Fincas" a selection by the following criteria was made: accessibility, residents on the lot, facility with an electric pump and productiveness of the well. In total three samplings were realized in January, February and March 2016.

For the screening in A January 36 domestic wells were sampled. In B February (23) and C March (10) the sample size was reduced to the most representative wells. The samples were realized employing a $\mathrm{pH}$-value measuring device (Voltcraft PH100 ATC), a conductivity measuring instrument (Greisinger GLF 100), and a multiparameter instrument (YSI Professional Plus) in order to measure insitu $\mathrm{pH}$, temperature, conductivity, salinity, total dissolved solids (TDS), chloride and nitrate. In addition pumping volumes and groundwater levels were documented as well as time, groundwater lowering and refill. Results were compared with the Mexican norm for drinking water NOM-127-SSA1-1994 from 22.11.2000 (table 1).

Table 1: Microbiological parameter of the European Council Directive $76 / 160 /$ EEC concerning the quality of bathing water.

\begin{tabular}{|l|c|c|c|c|}
\hline $\begin{array}{c}\text { Microbiological } \\
\text { parameter }\end{array}$ & $\begin{array}{c}\text { Volume } \\
\text { in } \mathrm{ml}\end{array}$ & $\begin{array}{c}\text { Recommended } \\
\text { value } \\
{[\mathrm{MPN} / 100 \mathrm{ml}]}\end{array}$ & $\begin{array}{c}\text { Limit } \\
{[\mathrm{MPN} / 100 \mathrm{ml}]}\end{array}$ & $\begin{array}{c}\text { NOM-127- } \\
\text { SSA1-1994 }\end{array}$ \\
\hline $\begin{array}{l}\text { Total coliform } \\
\text { bacteria }\end{array}$ & 100 & 500 & 10.000 & 2 \\
\hline $\begin{array}{l}\text { Fecal coliform } \\
\text { bacteria }\end{array}$ & 100 & 100 & 2.000 & 0 \\
\hline $\begin{array}{l}\text { Fecal } \\
\text { streptococcus }\end{array}$ & 100 & 100 & - & - \\
\hline
\end{tabular}

\subsection{Bacteriological investigation}

In the following step the bacteriological contamination was analyzed. There were already results of an investigation of the Universidad de Quintana Roo (UQROO) 
[3] indicating total and fecal coliform bacteria in different wells on Cozumel Island. In all wells a significant amount of both types of bacteria was found. For the present study six domestic wells were selected and sampled in February and March 2016 which proved to be highly representative because of their productiveness and using mode of their owners. The membrane filtration method according to ISO 7899-2:2000 was applied.

\subsection{Investigation of organic compounds}

In a final investigation at the end of the third sampling in March 2016 tests were carried out in two wells in "Las Fincas" and the sewage plant of CAPA for the following parameters: chemical oxygen demand (COD), biochemical oxygen demand (BOD5) and dissolved organic carbon (DOC). The following methods were applied: DIN 38409-41 (COD), DIN EN 1899-1 (BOD5) und DIN EN 1484 (DOC).

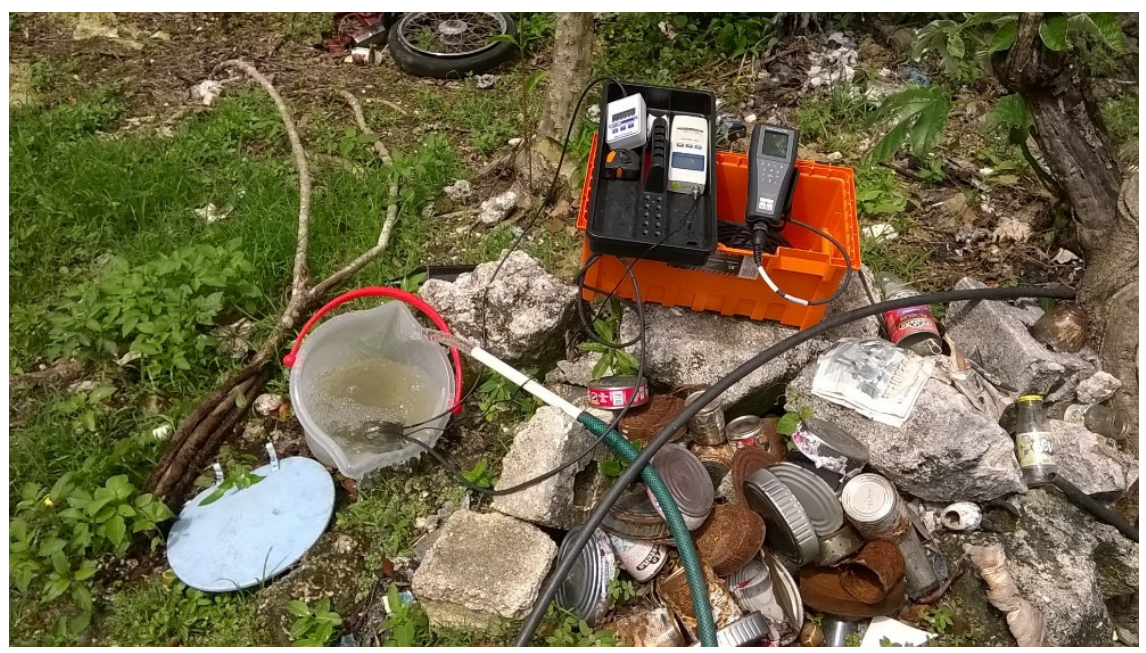

Figure 3: Measuring physico-chemical parameters.

\section{Results}

\subsection{Insitu-parameters}

The results of the in situ-parameters rarely showed differences in their spectrum. The anthropogenic contamination of the groundwater was indicated. Nitrate concentration $(10 \mathrm{mg} / \mathrm{l})$, TDS (1000 mg/l) exceeded the limits of the Mexican norm for drinking water (NOM-127-SSA1-1994 from 22.11.2000) in 25\% of domestic wells. The results did not indicate the intrusion of sea water.

Sporadically, some analyses showed increased parameters. Higher chloride concentrations could have their origin in the addition of chlorine tablets for disinfection by the owner of the domestic wells but also be an indicator for residual 


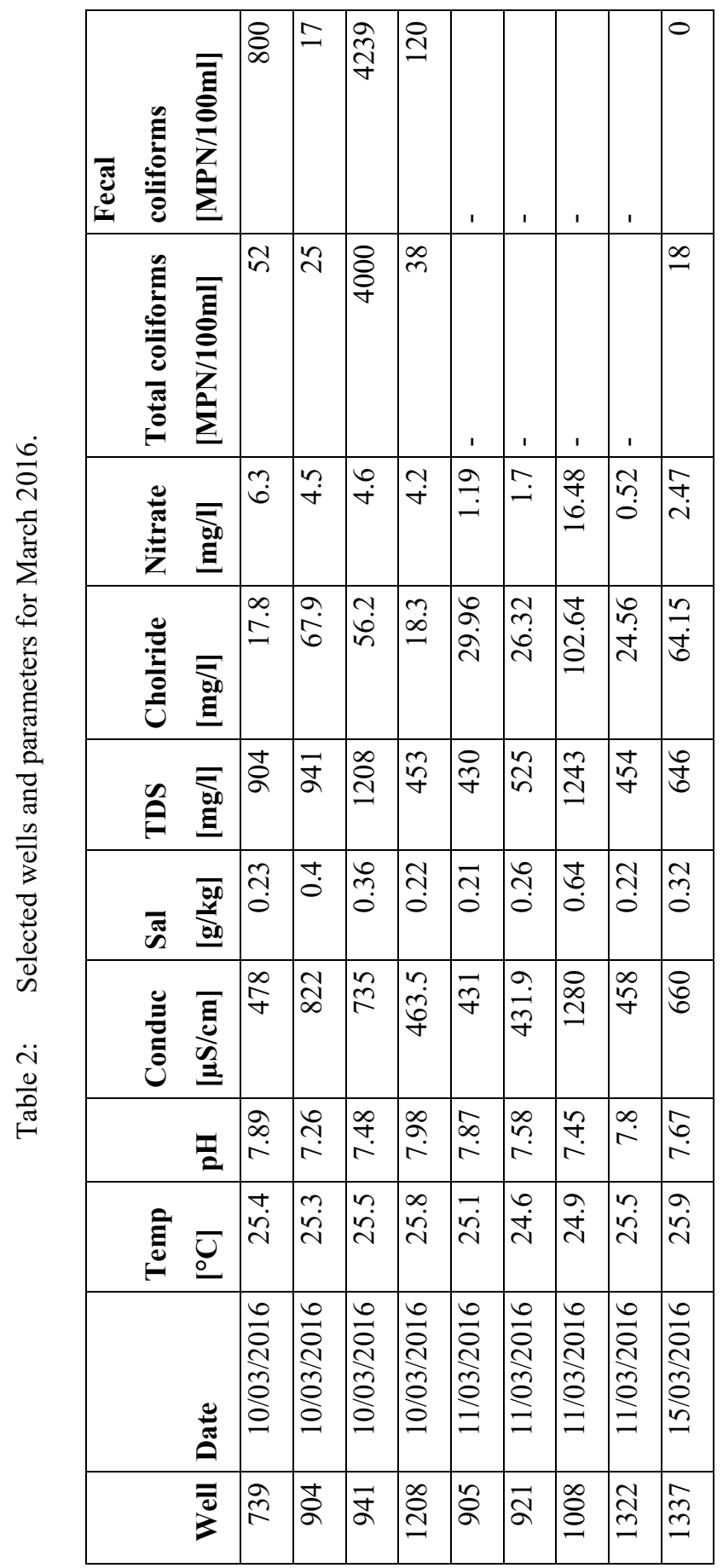


water. In some wells nitrogen compounds were higher which point to anthropogenic inputs. The results showed the influence of wastewater on the local aquifer as a consequence of the missing wastewater and waste disposal.

\subsection{Bacteriological and organic compounds}

In all domestic wells, even in the ones with chlorine tablets, high contamination of fecal indicator bacteria could be detected. Due to the fact that the contamination also was found outside of "Las Fincas" [3] it was necessary to clarify if the hygienic conditions in "Las Fincas" were the only reason for fecal bacteria in the groundwater. Further investigations discovered the practice of the grouting of treated wastewater by the local water supplier in the north of Cozumel Island about 6 kilometers away from "Las Fincas". CAPA grouts about 1.7 million cubic meters in 105 meters depth into the aquifer [14]. On the other hand there is an annual precipitation of 1175 millimeters and an annual groundwater recharge of 47.5 million cubic meters for Cozumel $[4,6]$.

Table 3: $\quad$ Organic compounds COD, BOD, and DOC in March 2016.

\begin{tabular}{|l|l|l|l|l|}
\hline Well & Date & COD [mg/l] & BOD5 [mg/l] & DOC [mg/l] \\
\hline 904 & $15 / 03 / 2016$ & $<15$ & $<2$ & 5 \\
\hline 1337 & $15 / 03 / 2016$ & $<15$ & $<2$ & 6.9 \\
\hline Sewage plant CAPA & $16 / 03 / 2016$ & 60 & 9 & 19 \\
\hline
\end{tabular}

The sampling results of the treated wastewater indicate typical concentrations for sewage plants. The wastewater parameters COD and BOD5 are not present but DOC show a distinct influence of organic substance in the groundwater.

\subsection{Documentation of groundwater levels}

With the help of the measured groundwater levels the hydroisohypses could be determined by creating hydrological triangles. Therefore, groups of three wells were connected to an equilateral triangle. By interpolation between groundwater levels in the wells and distance of the wells hydroisohypses could be calculated in order to detect groundwater flow directions and visualize them on a map $[8,9]$. During the sampling campaign in A January (36), B February (23) and C March (10) groundwater levels were measured in the domestic wells. In order to identify the flow direction of the groundwater seven wells were selected that were included in all three campaigns. Using the described method flow directions of these groups of wells were identified (figure 4).

\subsection{Groundwater flow directions}

The flow direction in January varied between east-southeast and south-southwest and moved by the decrease of precipitation to the south and southsouthwest (figure 4). However, the west and north-northwest directions were 


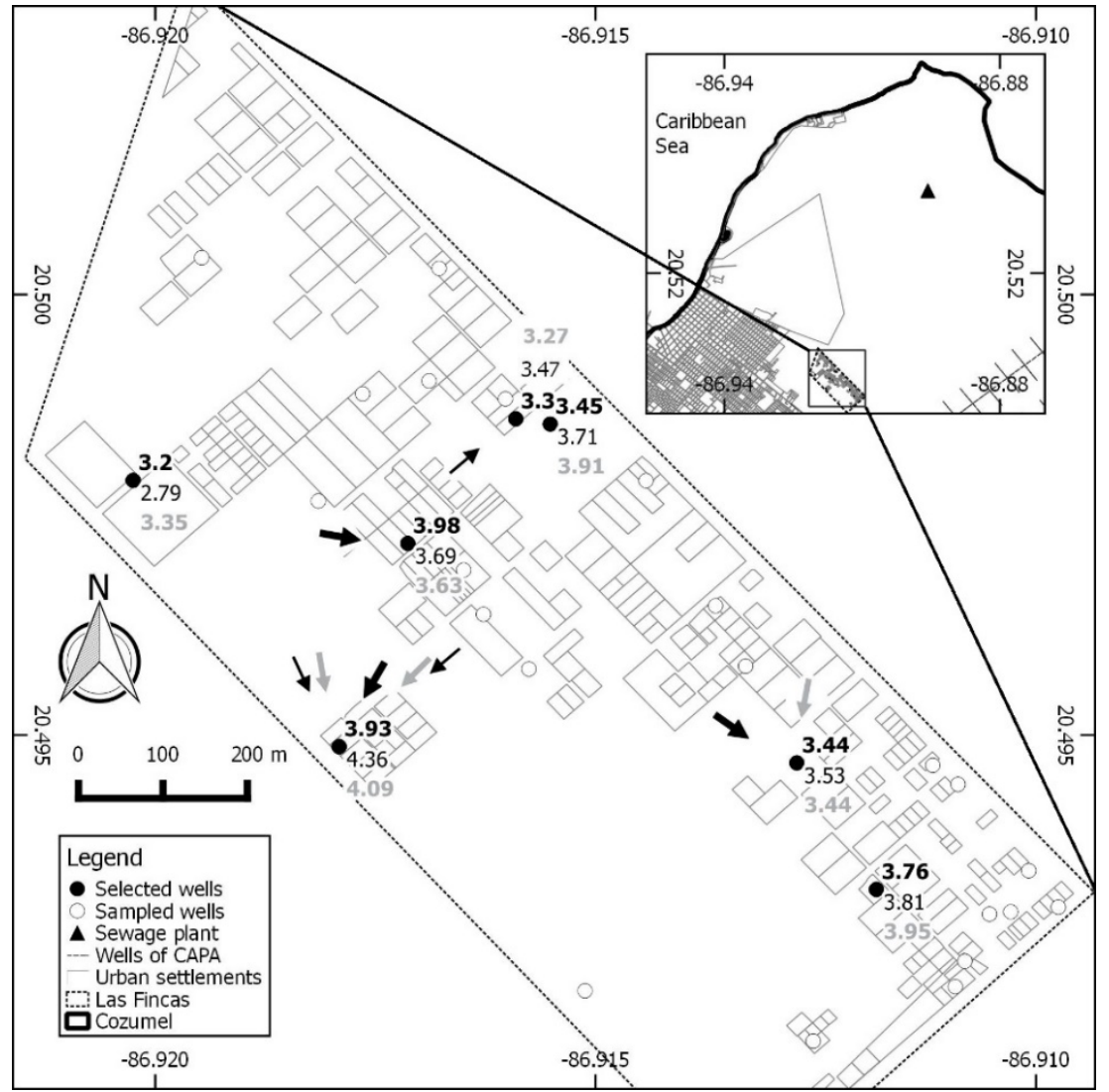

Figure 4: Groundwater levels (in meters below ground) and flow directions in January (black-bold), February (black) and March 2016 (grey).

exempted. The different flow directions can be described by the karstic aquifer and different weather seasons (rainy and dry season). The groundwater slope varied from $0.01 \%$ to $0.38 \%$. For the interpretation of the flow direction the monthly average precipitation was considered. On the other hand precipitation in the period during the sample campaigns was calculated (table 4). Groundwater levels in the sampled wells partly increased and partly decreased. No relation to weather seasons could be recognized.

Table 4: Precipitation on Cozumel Island in January, February and March 2016.

\begin{tabular}{|l|c|c|c|}
\hline Month & Campaign & $\begin{array}{l}\text { Average monthly } \\
\text { precipitation [mm] [1] }\end{array}$ & $\begin{array}{l}\text { Precipitation between } \\
\text { campaigns [mm] [1] }\end{array}$ \\
\hline January & A & 227 & $240(32$ days $)$ \\
\hline February & B & 80 & 93 (days) \\
\hline March & C & 32 & 35 (15 days) \\
\hline
\end{tabular}




\section{Further investigation on pharmaceuticals}

Numerous sampling campaigns show that residues of pharmaceutical ingredients continuously end up in the environment, especially in bodies of water. The reason for that is simple: active ingredients of pharmaceuticals often are poorly biodegradable and also mobile. They enter the environment by a side effect: the human body excretes many of the chemical substances unchanged. That is why every year many tons of active ingredients of pharmaceuticals and their degradation products arrive in the environment through the wastewater of the sewage plants. Many active ingredients are not filtered by sewage plants [7].

The Traugot Scheytt published concentrations of carbamazepine and diclofenac in the drainage of the sewage plant of Berlin Ruhleben, Germany, in the period November 2004 to June 2005 between 1 to 50 micrograms per liter [11].

Schramm et al. [12] mention concentrations of 6.3 to 46 micrograms per liter for urban wastewater. Carbamazepine was measured with a maximum concentration of 2.66 micrograms per liter in the groundwater.

It might be assumed that wastewater of the sewage plant of Cozumel Island also present concentrations of pharmaceuticals. For the long-term monitoring in 12 domestic wells in "Las Fincas" (starting in August 2016) is intended to examine pharmaceuticals by using them as an indicator for anthropogenic groundwater contamination.

\section{Conclusion}

The study area of the present investigation is the informal settlement "Las Fincas". There is neither any public water and power supply nor a sewerage system or waste disposal. The soil consists of karstified marine limestone. Due to its karstification the aquifer presents high vulnerability. The created data about groundwater quality in "Las Fincas" show a clear anthropogenic contamination which is indicated the pysico-chemical, bacteriological and organic parameters. The groundwater flow direction varies during the year depending on weather season and precipitation rates. Due to the flow directions some of the domestic wells in "Las Fincas" might be influenced by the grouted water of the sewage plant. Furthermore the wells of CAPA are located close to the settlement and could be affected by the contamination as well.

The missing wastewater and waste disposal as well as the practice of wastewater grouting into the karstic aquifer lead to a noticeable anthropogenic contamination in the domestic wells of "Las Fincas" which are used for water supply. Thus the situation presents a health risk for the residents of "Las Fincas". In addition, wells of CAPA are in risk of contamination due to their close location to "Las Fincas" and calculated groundwater flow directions.

There are different methods for providing water without any health risks due to bacteriological contamination. The decoction of small amounts of water presents the most meaningful alternative for a daily application. Frequent disinfection with chloride for larger volumes of water is possible, but requires appropriate storage tanks with sufficient capacity. The third method is the application of a photo- 
electrolytic system. Water passes between two metal electrodes where solar electricity generates a small current that in turn produces minute amounts of chlorine, thereby destroying all harmful bacteria immediately. This last method is the most effective and reliable one to treat large volumes of groundwater for human use. This kind of system requires a high investment at the beginning, which will quickly amortize.

The goal for future investigations is to observe the hydrodynamic and hydro chemical conditions with the help of the installed long term monitoring. Different indicators like pharmaceutical can proof contamination caused by the wastewater grouting of the CAPA's sewage plant.

\section{Acknowledgements}

The authors would like to thank CAPA (Comisión de Agua Potable y Alcantarillado) for their support in the analysis of water samples, Professor Adrián Cervantes-Martínez of the University of Quintana Roo (UQROO) for providing measuring equipment and the German Academic Exchange Service (DAAD) for the financial support to Christian Koch in form of a scholarship which made field work possible. Finally this paper is the result of the academic exchange between the UQROO and the University of Applied Science (UAC) Jena. We thank these institutions and all responsible person for their collaboration.

\section{References}

[1] Alpuche Castillo, A., Interview, 16 April 2016, Chief of Weather Forecast, Comisión Nacional del Agua (CONAGUA), Quintana Roo, Mexico.

[2] Bayerisches Landesamt für Wasserwirtschaft (BLfW), Schlussbericht: Quantifizierung der diffusen Belastung von Gewässern mit Fäkalbakterien aus landwirtschaftlich genutzten Flächen, Munich, Germany, January 2004. https://www.lfu.bayern.de/analytik_stoffe/biol_analytik_mikrobielle_oekol ogie/bakterien_schaedlinge/doc/abschwemmung.pdf

[3] Chi Chiclin, J., López Mejía, M., Téllez Díaz, G., Quinones Campos, S., Estudio comparativo de la calidad bacteriológica del agua de la isla de Cozumel, Quintana Roo, México. http://www.coqcyt.gob.mx/portal/ cuenca/Contenido/Presentaciones $\% 20$ foro/ok\%20Panel\%203/P3 06Chi\%20et\%20al,\%202011.pdf

[4] Coral Zaragoza, E., Diagnóstico del Estado de Implementación del Indicador Grado de Presión Hídrico sobre el Acuífero de la Isla de Cozumel. 90-91, 2015.

[5] Escalante, P., Conabio: Portal de Geoinformación, 1996. Retrieved from Shapefile "Tipos de vegetación de la Isla de Cozumel, Quintana Roo": http://www.conabio.gob.mx/informacion/gis/

[6] Frausto Martínez, O., Rojas, J., Ihl, T., \& Morales, N., Atlas de riesgo, vulnerabilidad y peligros de la isla de Cozumel. Chetumal: D. R. Universidad de Quintana Roo, pp. 31-39, 2014. 
[7] German Federal Environmental Agency, Dessau, Arzneimittel und Umwelt, 2014. http://www.umweltbundesamt.de/themen/chemikalien/arzneimittel/ arzneimittel-umwelt

[8] Hölting, B., Hydrogeologie: Einführung in die allgemeine und angewandte Hydrogeologie (4 th edition), Stuttgart: Ferdinand Enke Verlag, 1992.

[9] Kallnischkies, T., Demolition Blog, Hydrological Triangles, 25 October 2011. http://desastre.eu/demolition/?tag=hydrological-triangle

[10] Lesser, H., Azpeita, J., \& Lesser, J., Geohidrología de la Isla de Cozumel, Q. Roo. Recursos Hidráulicos, 6(1), pp. 32-50. http://lesser.com.mx/files/ 78-1Geohidrologia-Isla-de-Cozumel,-Q-Roo.pdf

[11] Schett, T., Geo-Union; Technical University Berlin, Arzneimittel im Grundwasser: Bedeutung von Spurenstoffen im aquatischen System, Germany, 2011. http://www.geo-union.de/fileadmin/downloads geounion/ LWEL2011 Vortrag_Scheytt.pdf

[12] Schramm, C., Gans, O., Uhl, M., Grath, J., Scharf, S., Zieritz, I., . . . Humer, F., Carbamazepin und Koffein - Potenzielle Screeningparameter für Verunreinigungen des Grundwassers durch kommunales Abwasser?, Austrian Federal Environmental Agency, Vienna, 2006. http://www.umweltbundesamt.at/fileadmin/site/publikationen/REP0061.pdf

[13] Spektrum der Wissenschaft Verlagsgesellschaft mbH, Karst: Lexikon der Geowissenschaften. http://www.spektrum.de/lexikon/geowissenschaften/ karst/8099

[14] Telléz Diaz, Personal Communication, 16 March 2016, Head of Technical Maintenance, Comisión de Agua Potable y Alcantarillado (CAPA), Cozumel, Mexico.

[15] Wurl, J., \& Giese, S., Groundwater Quality Research on Cozumel Island, State of Quintana Roo, Mexico. In O. Frausto Martínez, Desarrollo sustentable: Turismo, costas y educación (S. 171-176). Cozumel: Universidad de Quintana Roo, 2005. 